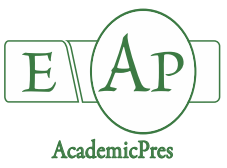

Zengin S et al. (2020)

Notulae Botanicae Horti Agrobotanici Cluj-Napoca 48(1):388-397

DOI: $10.15835 /$ nbha48111732

Research Article

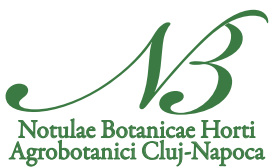

\title{
Relationship between some morphological traits of the tomato lines and resistance to tomato yellow leaf curl virus disease
}

\author{
Sinan ZENGIN ${ }^{1 *}$, Aylin KABAS ${ }^{2}$, Hulya ILBI ${ }^{3}$ \\ ${ }^{1}$ Antalya Agriculture Production Consultancy and Marketing Company, Antalya, \\ Turkey; erenzengin2019@gmail.com (*orrespondingauthor) \\ ${ }^{2}$ Akdeniz University, Manavgat Vocational School, Antalya, Turkey; demirelliaylin@hotmail.com \\ ${ }^{3}$ Ege University, Faculty of Agriculture, Department of Horticulture, Izmir, Turkey; hulyailbi@gmail.com
}

\begin{abstract}
Tomato (Solanum lycopersicum L.) is the most produced and exported vegetable in Turkey. There are many pathogens to limit tomato production by reducing yield and fruit quality. Among them, Tomato Yellow Leaf Curl Virus (TYLCV) causes important economic losses. The most efficient and environmentally friendly method against TYLCV is the use of resistant varieties. In this trial, it was aimed to determine some morphological traits which were linked to $T y-1$ and $T y$-3a genes which confer to TYLCV. A commercial hybrid carrying $T y-1, T y$ - $3 a$ genes as heterozygous was crossed to a susceptible inbred line from Bati Akdeniz Agricultural and Research Institute (BATEM). Marker assisted selection (MAS) was carried out in F1 and F2 generations and biological tests were done for TYLCV resistance in F3 generation. MAS for $T y-3 a$ and $T y-1$ genes were compatible with biological tests. In total of 95 genotypes in F3 were developed with molecular marker selection. It was determined that 30 genotypes having the $T y$ - $3 a$ and $T y-1$ genes as homozygous resistant. The nine genotypes carried these genes in heterozygous form. 56 genotypes were identified as susceptible. The 43 morphological traits were observed in identified individuals to correlate with resistant allele, $T y$-3a. It was found that there was statistically important correlation between $T y$ - $3 a$ and length of internode, length of stem at first inflorescence, status of calix, leaf attitude, length of inflorescence and plant habitus. Also, there was negative correlation between fruit weight, fruit length and resistance. Therefore, we identified some morphological markers linked to $T y$-3a which can be used in selection for TLYCV resistant breeding programme.
\end{abstract}

Keywords: biological test; MAS; morphological traits; tomato; ty-3a, resistance

\section{Introduction}

Tomato (Solanum lycopersicum L.,) is one of the most economically important vegetables in the world. The world tomato production is over 163 million tons from an area of 4.83 million hectares (FAO, 2017). Yield, fruit quality, shelf-life, and nutritional content are reduced when tomato crops can be infected by diseasecausing bacterial, fungal, and viral pathogens (Oerke, 2006; Hanson et al., 2016). Among the virus diseases, the tomato yellow leaf curl virus (TYLCV) is the most destructive disease and causes loss of yield between $85 \%$ and 100\% (Pico et al., 1996; Czosnek and Laterrot, 1997; Polston and Anderson, 1997). TYLCV is transmitted by 
the whitefly Bemisia tabaci (Zamir et al., 1994; Ghanim and Czosnek, 2000). Domestic S. lycopersicum species were found to be susceptible to TYLCV by (Hassan et al., 1991). But some wild tomato species have been discovered as resistant source for TYLCV (Pico et al., 1996; Scott, 2007). Among the identified six loci (Ty-1 to $T y-6)$ for TYLCV resistance, $T y-3, T y-3 a$ and $T y-1$ genes mapped on chromosome 6 provide a very large part of the resistance. $T y$-3, $T y$-3a genes were obtained from $S$. chilense accessions such as LA2779 and LA1932, respectively (Ji et al., 2007), Ty-1 gene was obtained from LA1969 (Zamir et al., 1994).

Although $T y-3$ gene provides wide resistance, $T y$ - $3 a$ gene is mostly preferred in breeding program because of many undesirable morphological traits that are related with $T y-3$ gene. There is no effective chemical treatment to control viral diseases that results in severe damage, such as TLYCV, therefore, the use of resistant varieties is the best and environmentally friendly method for pathogen management (Cho et al., 1995; Oerke, 2006; Mutlu et al., 2015). Furthermore, the gene pyramiding that combines multi-resistant genes in a variety via molecular markers, has been an important component of modern tomato breeding programme. Tomato is very rich in the number of available molecular markers (Foolad, 2007), thus marker assisted selection (MAS) in tomato breeding programme have been effectively used for transferring of many disease resistance genes. It has been shown that some of resistant genes were in the linkage with other genes, having epistatic properties (Gómez et al., 2004; Mejía et al., 2005; Rani et al., 2008; Consuegra et al., 2015). Therefore, the aim of this research is to determine whether there is a relationship between morphological traits and $T y-1$ and $T y-3 a$, resistant genes against to TYLCV. Thus, it is possible to make a selection via morphological markers linked to the TLYCV genes, as an alternative MAS in resistance breeding.

\section{Materials and Methods}

\section{Plant material}

Segregation populations (F1, F2 and F3) were obtained by crossing a susceptible line with a heterozygous resistant commercial variety ('TayfunF1'). 'Tayfun F1' having $T y-1$ and $T y$-3a genes was obtained from Antalya Seed Company. Susceptible line called BATEM1 from Bati Akdeniz Agricultural Research Institute (BATEM), had fruit weight of $180 \mathrm{~g}$. $T y-1$ and $T y-3 a$, genes via molecular markers were screened in F1, F2 and F3 population.

\section{Molecular markers and PCR amplifications}

Genomic DNA of the parents and F1, F2, F3 individuals was isolated from the fresh leaves according to CTAB method (Doyle and Doyle, 1987). The presence of the resistance genes $T y-1$ and $T y$ - $3 a$ was investigated essentially, using CAPS JB1 (De Castro et al., 2007) and SCAR P6-25 (Ji et al., 2007) primers, respectively. Amplifications were performed in thermalcycler in a $20 \mu \mathrm{L}$ final volume, containing $25 \mathrm{ng}$ of genomic DNA, $1 \mathrm{X}$ reaction buffer, $0.5 \mathrm{mM}$ of $\mathrm{MgCl}_{2}, 0.6 \mathrm{mM}$ of each $\mathrm{dNTP}, 0.5 \mu \mathrm{M}$ of each primer and $1 \mathrm{U}$ of Taq DNA polymerase. For the marker of $T y$ - 1 , the PCR programme was as follows after initial denaturation for $2 \mathrm{~min}$ at $95^{\circ} \mathrm{C} .19$ cycles of $10 \mathrm{~s}$ at $94^{\circ} \mathrm{C}, 30 \mathrm{~s} 55^{\circ} \mathrm{Cs}, 1 \mathrm{~min} 10 \mathrm{~s} 72^{\circ} \mathrm{C}$ and 9 cycles of $10 \mathrm{~s} 94^{\circ} \mathrm{C}, 30 \mathrm{~s} 53^{\circ} \mathrm{C}, 1 \mathrm{~min} 10 \mathrm{~s}$ $72^{\circ} \mathrm{C}$ and a final extension of $5 \mathrm{~min}$ at $72^{\circ} \mathrm{C}$.

After PCR amplification, $5 \mu \mathrm{l}$ of the PCR products were digested with the restriction enzyme Taq1 following the manufacturer protocol (Thermo Fisher Scientific). In the case of the marker of $T y-3 a$, named P6-25, the PCR reaction was as follows: denaturation for $4 \mathrm{~min}$ at $94^{\circ} \mathrm{C}, 34$ cycles each consisting of $30 \mathrm{~s}$ at 94 ${ }^{\circ} \mathrm{C}, 60$ s at $53^{\circ} \mathrm{C}, 60$ s at $72{ }^{\circ} \mathrm{C}$ and a final extension of $10 \mathrm{~min}$ at $72^{\circ} \mathrm{C}$.

All PCR products were separated on a $1.5 \%$ agarose gel (Sigma, St. Louis, MO), visualized with ethidium bromide under UV light. 


\section{TYLCV inoculation and disease screening}

The seedlings were grown in equal volume of steam-sterilized perlite: peat mix. The experiment was conducted in a completely randomized block with two replicates and ten plants were tested each replicate. 'Tayfun F1' (as resistant hybrid), Batem Ozcelik F1 (as susceptible hybrid) and F3 individuals, were inoculated with Whiteflies (Bemisia tabaci, Biotype B =Bemisia argentifolii) collected from cotton plants (Gossypium hirsutum). Inoculation test was carried out in insect-proof wooden cages at $24-27{ }^{\circ} \mathrm{C}$ in a controlled temperature room provided with $16 \mathrm{~h}$ illumination per day (Zeidan and Czosnek, 1991). To transmit the virus, whiteflies were grown on TYLCV-infected tomato plants. TYLCV was acquired by whiteflies during a 48-h acquisition access period on TYLCV-infected tomato plants. The plants were scored at 56 days after inoculation based on symptoms or no symptoms on the leaves (Scott and Schuster, 1991).

\section{Morphological traits}

95 F3 individuals which were selected by molecular markers, were also evaluated based on 43 morphological traits according to UPOV criteria (Table 1).

Table 1. Morphological traits

\begin{tabular}{|c|c|}
\hline Plant growth habit & determinate, indeterminate, semi determinate \\
\hline Length of plant & short, medium, long \\
\hline Plant stem thickness & weak, medium, strong \\
\hline Stem: length of internode & short, medium, long \\
\hline Length of stem at first inflorescence & short, medium, long \\
\hline Stem hairs & weak, medium, strong \\
\hline Leaf: attitude & erect, horizontal, drooping \\
\hline Plant habitus & weak, medium, strong \\
\hline Leaf: length & short, medium, long \\
\hline Leaf width & narrow, medium, broad \\
\hline Leaf: intensity of green color & light, medium, dark green \\
\hline Flower sepal color & yellow, white \\
\hline Fruit set on Inflorescence & weak, medium, strong \\
\hline Fruit green shoulder (before maturity) & absent, present \\
\hline Fruit: intensity of green color (before maturity) & light, medium, dark green \\
\hline Length of inflorescence & short, medium, long \\
\hline Inflorescence type & uniparous, forked, multiparous or irregular \\
\hline Number of fruits on second inflorescence & average 5 plants \\
\hline Uniformity of fruit on plant & bad, medium, good \\
\hline Fruit weight & average of 10 fruits \\
\hline Status of calix & horizontal, medium, vertical \\
\hline Thickness of calix & weak, medium, strong \\
\hline Colors of petal & light, medium, dark green \\
\hline Length of fruit stalk & short, medium, long \\
\hline Presence of jointless pedicel & flattened, slightly flattened, strong flattened \\
\hline Size of dry section around the fruit & small, medium large \\
\hline Predominant fruit shape (After the fruit turns color) & flattened, oblate, circular, oblong, elliptic, or obovate \\
\hline Fruit width & average of 5 fruits \\
\hline Fruit length & average of 5 fruits \\
\hline Green shoulder (at maturity) & absent, present \\
\hline Fruit: shape at blossom end & indented, indented to flat, flat to pointed, pointed \\
\hline
\end{tabular}




\begin{tabular}{|c|c|}
\hline Size of blossom end & small, medium, large \\
\hline Blossom end shape & indented, flat, pointed \\
\hline Fruit color intensity at maturity & dark, light \\
\hline Fruit: firmness & very soft, very firm \\
\hline Transvers section & round, angular, irregular \\
\hline Fruit: thickness of pericarp & average 5 fruits \\
\hline Size of fruit locules & small, medium, big \\
\hline Fruit number of locules & average 5 fruits \\
\hline Fruit puffiness at maturity & absent, present \\
\hline Fruit concentric cracks at maturity & absent, present \\
\hline Fruit radial cracks at maturity & absent, present \\
\hline Cat face at maturity & absent, present \\
\hline
\end{tabular}

\section{Data analyses}

The correlation between the disease resistance gene and 43 traits were analysed by using Pearson correlation analysis in SPSS 14.0 program.

\section{Results and Discussion}

\section{Segregation of $T y$ - 1 and $T y$-3a by molecular markers}

F1 plants which were obtained by crossing Tayfun F1 and BATEM1 pure line, were screened with molecular markers linked to $T y-1$ and $T y-3 a$. F2 and F3 can be obtained by selfing F1 and F2 plants. Individuals of F2 and F3 population were screened via molecular markers to determine segregation of the $T y-1$ and $T y-3 a$ genes.

\section{Ty-1 gene}

Ty-1 gene had two allelic forms based on molecular marker (JB1). The susceptible pure lines had susceptible allele (tyl:ty1) at $400 \mathrm{bp}$ and commercial hybrid was heterozygous form having band at $400 \mathrm{bp}$ for susceptible allele and $500 \mathrm{bp}$ for resistant allele. The susceptible individuals of F2 and F3 had allele at 400 bp and resistant individuals had alleles at both 400 and $500 \mathrm{bp}$ (Figure 1).

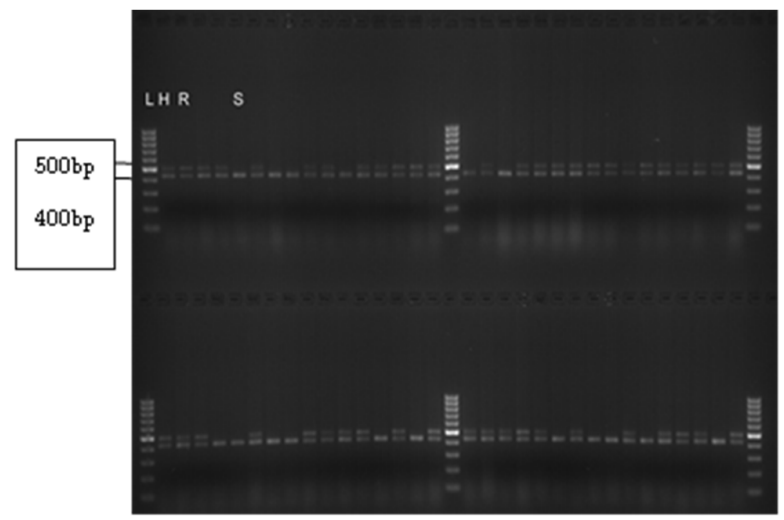

Figure 1. PCR fragments represent CAPS JB1 marker for $T y-1$ gene. Susceptible individuals of F2 and F3 had alleles at $400 \mathrm{bp}$ and resistant individuals had alleles at both 400 and 500 bp.L: 100 bp DNA ladder, $\mathrm{R}$ : homozygous resistant, $\mathrm{H}$ : heterozygote resistance, $\mathrm{S}$ : Susceptible genotypes 


\section{Ty-3agene}

Two different allelic forms for Ty3a were observed in F1 individuals, that susceptible ones had allele at $320 \mathrm{bp}$ and heterozygous individual carried alleles at 320 and $630 \mathrm{bp}$. The individuals of segregating populations carried three different allelic forms at $320 \mathrm{bp}$ for susceptible or at both $320 \mathrm{bp}$ and $630 \mathrm{bp}$ for heterozygous resistant or at $630 \mathrm{bp}$ homozygous resistant (Figure 2). The $T y$ - $3 a$ gene is more preferred due to the fact that the $T y-3$ gene provides a wider durability, and many other features are undesirable with the gene.

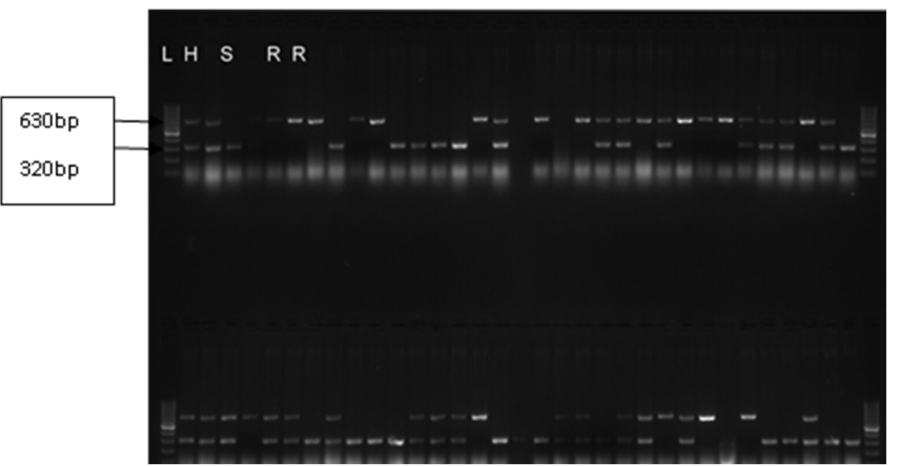

Figure 2. PCR fragments represent SCAR P6-25 marker for Ty-3a gene. The individuals of segregating populations carried three different allelic forms at $320 \mathrm{bp}$ for susceptible or at both $320 \mathrm{bp}$ and $630 \mathrm{bp}$ for heterozygous resistant or at 630 bp homozygous resistant. L: 100 bp DNA ladder, R: homozygous resistant, $\mathrm{H}$ : heterozygote resistance, $\mathrm{S}$ : Susceptible genotypes

Segregation ratios for resistant and susceptible individuals for F1 were checked with Chi-square test. The resistant Tayfun F1 was crossed with the susceptible line to obtain F1 plants which segregated resistant and susceptible plants in a 1:1 ratio (Table 2). According to $\chi^{2}$ (Chi-square) analysis, $T y$ - 1 and $T y$ - $3 a$ based on molecular marker show equal segregation at statistical significance level of 0.05 .

Table 2. The segregation analysis of reaction of $\mathrm{F} 1$ plants resistance to $T y$ - 1 and $T y$ - $3 a$ genes

\begin{tabular}{|c|c|c|c|}
\hline \multirow{2}{*}{ Gene } & Phenotypic segregation & \\
\cline { 2 - 3 } & Observed F1 plants & Expected F1 plants & Chi-square $\left(\chi^{2}\right)$ \\
\hline Tyltyl & 190 & 200 & \multirow{2}{*}{1.0} \\
\hline tyltyl & 210 & 200 & \\
\hline Ty3aty3a & 190 & 200 & 200 \\
\hline ty3aty3a & 210 & & \\
\hline
\end{tabular}

The segregation of the $T y$ - $3 a$ gene in F2 population tested by molecular marker was homozygous resistant in 99 individuals and heterozygous resistant in 194 individuals and homozygous susceptible in 107 individuals. Moreover, the 107 susceptible individuals for $T y$ - $3 a$ were also found to be susceptible for the $T y$ - 1 gene (Table 3).

Table 3. The segregation analysis of reaction of F2 plants resistance to $T y-1$ and $T y$ - $3 a$ genes

\begin{tabular}{|c|c|c|c|c|c|c|c|}
\hline & \multicolumn{3}{|c|}{ Observed F2 plants } & \multicolumn{3}{c|}{ Expected F1 plants } & Chi- square \\
\hline & $\mathrm{RR}$ & $\mathrm{Rr}$ & $\mathrm{Rr}$ & $\mathrm{RR}$ & $\mathrm{Rr}$ & $\mathrm{rr}$ & \\
\hline Ty3 & 99 & 194 & 107 & 100 & 200 & 100 & 0,68 \\
\hline Ty1 & \multicolumn{2}{|c|}{293} & 107 & \multicolumn{2}{|c|}{300} & 100 & 0,65 \\
\hline
\end{tabular}

$\mathrm{X}^{2}(0.05)=3.84, \mathrm{RR}$ : Homozygot resistant, Rr: heterozygote resistant, rr: susceptible 
Chi-square analysis was used to determined segregation ratio for $T y-1$ and $T y-3 a$ in F2 population. According to results segregation ratio was evaluated the same distribution at statistical significance level of 0.05 (Figures 3 and 4).

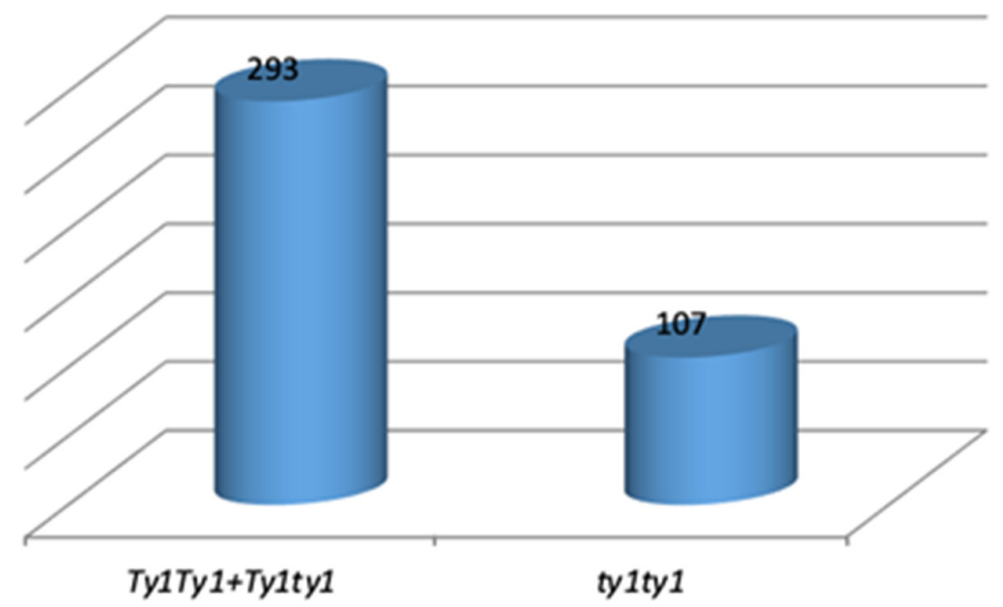

Figure 3. Segregation of F2 genotypes in terms of $T y$ - 1 gene

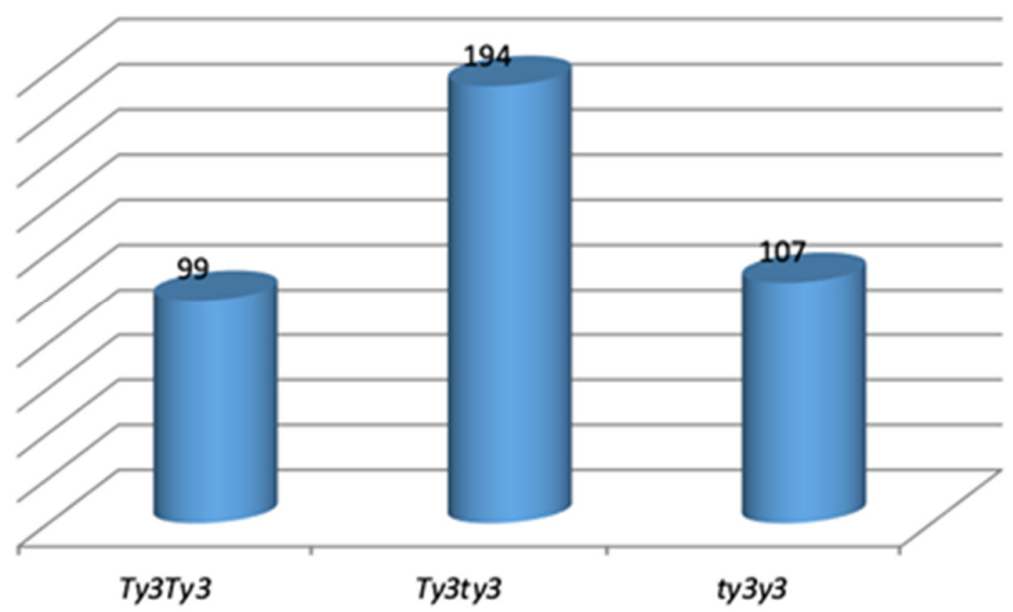

Figure 4. Segregation of F2 genotypes in terms of $T y$ - $3 a$ gene

Ty-1 gene

Although three different alleles (allele 1 at $400 \mathrm{pb}$, allele 2 at slightly larger than $400 \mathrm{pb}$ and allele 3 at $500 \mathrm{pb}$ ) for TY-1 gene; were identified by De Castro et al. (2007), in our research the individuals of segregating populations and parents had two alleles. Also, allele at $500 \mathrm{bp}$ were dominant over allele at $400 \mathrm{bp}$.

\section{Ty-3agene}

The individuals of segregating populations carried three different allelic forms at $320 \mathrm{bp}$ for susceptible or at both $320 \mathrm{bp}$ and $630 \mathrm{bp}$ for heterozygous resistant or at $630 \mathrm{bp} \mathrm{homozygous} \mathrm{resistant} \mathrm{(Ji} \mathrm{et} \mathrm{al.,} \mathrm{2007).} \mathrm{The}$ Ty-3a gene is more preferred due to the fact that the $T y-3$ gene provides a wider durability, and many other features are undesirable with the gene. 
Segregation ratios for resistant and susceptible individuals for F1 were checked with Chi-square test. In this research it was determined that $T y-1$ and $T y$-3a genes did not segregate in the segregating populations and all individuals had both alleles together. These results also provided that $T y-1$ and $T y$-3a were alleles of the same gene (Ji et al., 2007; Verlaan et al., 2013).

\section{Disease assessment}

In the biological test 'Tayfun F1' (as resistant hybrid), 'Batem Ozcelik' F1 (as susceptible hybrid) and F3 individuals, inoculated with Whiteflies. There were no symptoms of resistant control varieties while susceptible hybrid showed disease symptoms. Ten F3 individuals which were determined as homozygous resistant by molecular marker for $T y-1$ and $T y-3 a$, were also found to be resistant by biological test. Disease symptoms were not observed in the resistant F3 individuals. In contrast, F3 individuals which were evaluated as susceptible with molecular marker, showed the disease symptoms. There were no disease symptoms in only one plant of each susceptible DT-27, DT-37, DT-224, DT-246 individuals and 2 plants in susceptible DT-109 individual.

The individuals determined as heterozygous via marker test in the F2 generations segregated as 3:1 ratio based on biological test in F3 generations. According to the chi-square analysis, it was determined that the distribution at 0.05 level was 3:1 ratio. Some breeders could obtain false data in negative and positive results because they can't calculate the distance of markers P6-25 stated (Jensen et al., 2007).

Especially; emphasized that faulty results could be obtained from the sources transferred from different wild species of tomato to culture tomato. However, our results of the marker and biological testing were found to be compatible with each other.

\section{The relationship between the characteristics of the lines and disease resistance}

In the total $95 \mathrm{~F} 3$ individuals were evaluated based on both morphological traits and disease resistance. The 56 individuals were determined as a susceptible 9 individuals were heterozygous resistance and 30 individuals were homozygous resistant by molecular markers.

There was statistically significant positive correlation between $T y-3 a$ and $T y-1$ genes and lengths of stem at first inflorescence, stem length of internode, leaf attitude, plant habitus, length of inflorescence and status of calix position of petal (Table 4). The length of stem at first inflorescence and stem length of internode directly affects the yield of tomato production. According to (Balliu and Hallidri, 2002), the length of internode was determined by the addition effect. Indeterminate varieties have less cluster than determinate varieties so the yield is decrease in indeterminate varieties. For this reason, breeders have preferred the varieties which have short length of stem at first inflorescence and short stem length of internode.

However, in this research we determined that as the stem length of internode and the length of inflorescence in tomato increased, the tomato individuals carried homozygous $T y$ - $3 a$ gene. Also, the leaf size and the length of internode were determined to be significant in reduction at susceptible tomato plants (Padidam et al., 1995). Therefore, it can be stated that the length of internode can be used as selection criteria for resistant breeding programme in tomato.

Leaf attitude was evaluated at three different position (erect, horizontal, drooping) according to UPOV. There was a significant positive correlation between resistance to TLYCV and leaf attitude (Table 4).

The individuals having leaf at dropping position was resistant to TLYCV indicating that these genotypes carried $T y$ - $3 a$ gene. The producers and breeders generally prefer the tomato variety with horizontal leaf position to prevent the transmission of fungal diseases. Because it believes that the horizontal leaf position can allow the plants to get better air. In contrast to this, we determined that the resistant tomato individuals had drooping leaf position.

Plant habitus was evaluated as weak, medium and strong type. The plant habitus of the resistant tomato individuals were weak type. Also, the resistant tomato individuals had long length of inflorescence. Although 
not statistically significant, there was a negative correlation between resistance to TLYCV and fruit characteristics such as fruit weight and fruit length (Table 4).

Table 4. The correlation coefficient value between disease resistance genes and morphological traits

\begin{tabular}{|c|c|c|c|}
\hline Traits & Ty-3a and $\boldsymbol{T y}$-1 & Traits & Ty-3a and $\boldsymbol{T} \boldsymbol{y}$-1 \\
\hline Plant growth habit & 0.11 & Congth of fruit stalk & 0.06 \\
\hline Length of plant & -0.12 & -0.33 \\
\hline Plant stem thickness & -0.14 & Presence of jointless pedicel & -0.08 \\
\hline Stem: length of internode & $\mathbf{0 . 2 3}$ & Size of dry section around the & 0.06 \\
\hline Length of stem at first & $\mathbf{0 . 2 3}$ & Predominant fruit shape & 0.00 \\
\hline Stem hairs & 0.00 & Fruit length & $\mathbf{- 0 . 2 0}$ \\
\hline Leaf: attitude & $\mathbf{0 . 2 6 *}$ & Fruit width & -0.17 \\
\hline Plant habitus & $\mathbf{0 . 3 0 * *}$ & Green shoulder (at maturity) & -0.02 \\
\hline Leaf: length & -0.09 & Fruit: shape at blossom end & 0.11 \\
\hline Leaf width & -0.08 & Size of blossom end & 0.06 \\
\hline Leaf: intensity of green colour & -0.07 & Blossom end shape & -0.17 \\
\hline Flower sepal colour & 0.00 & Fruit colour intensity at & -0.15 \\
\hline Fruit set on Inflorescence & -0.13 & Fruit: firmness & 0.09 \\
\hline Fruit green shoulder before & -0.13 & Transvers section & -0.17 \\
\hline Fruit: intensity of green colour & -0.01 & Fruit: thickness of pericarp & -0.14 \\
\hline Length of inflorescence & $\mathbf{0 . 4 0 * *}$ & Size of fruit locules & -0.18 \\
\hline Inflorescence type & 0.16 & Fruit number of locules & 0.13 \\
\hline Number of fruits on second & -0.14 & Fruit puffiness at maturity & -0.14 \\
\hline Uniformity of fruit on plant & 0.00 & Fruit concentric cracks at & 0.00 \\
\hline Fruit weight & $\mathbf{- 0 . 1 8}$ & Fruit radial cracks at maturity & -0.01 \\
\hline Status of calix Position of petal & $\mathbf{0 . 2 4 *}$ & Cat face at maturity & -0.13 \\
\hline Thickness of calix & -0.06 & & \\
\hline
\end{tabular}

As the fruit weight decreased, the resistance to TYLCV increased. It was also determined that fruit size was affected with resistance gene and homozygous resistant gene resulted in the middle-small fruit group (Consuegra et al., 2015). Two QTLs for fruit weight were identified on chromosomes 2 and the wild alleles were associated with a reduction in fruit weight (Chen et al., 1999; Grandillo et al., 1999; Doganlar et al., 2002). Five QTLs were identified for fruit length and similarly the most significant QTL for fruit length was detected on chromosome 2 (Doganlar et al., 2002).

The transfer of resistance genes from wild genotypes to culture forms were affected both the fruit and the morphological structure of the genotypes (Tanksley, 2004). As (Gómez et al., 2004; Mejía, 2005) pointed, we determined that the resistant individuals had undesirable plant traits such as reduction of the number of fruits per plant and fruit traits. (Consuegra et al., 2015) also found a statistically significant and negative correlation between resistance to TLYCV and the number of fruits in the first 4 clusters, the number of branches per plant, the number of fruits per plant and yield per plant.

It can be stated that in breeding programs for resistance which don't use marker technology, resistant genotypes can be eliminated due to their undesirable fruit and plant characteristics such as small sized fruit, weak plant habitus, a smaller number of fruits per plant. 


\section{Conclusions}

Molecular Marker Assisted Selection (MAS) has been successfully used to select resistant genotypes in the breeding study. In this research, we identified 95 individuals of F3 population based on their morphologic traits and their resistance to TLCV by molecular markers linked to Ty- 1 and Ty3-a and by biological test. It was determined the 30 individuals having homozygous resistant alleles, the 9 individuals having heterozygous alleles for both $T y$ - $3 a$ and $T y-1$ genes. The 56 individuals were susceptible against to TLYCV.

In our study, it was found that the $T y-1$ and $T y$ - $3 a$ genes did not segregated in any individuals and were together in all individuals. Thus, it can be concluded that $T y-3 a$ and $T y-1$ genes could be allele genes. The 43 morphological traits were observed in the selected individuals of the F3 population by molecular marker to correlate with resistant allele, $T y$ - $3 a$. It was found that there was statistically significant correlation between Ty-3a and length of internode, length of stem at first inflorescence, status of calix position of petal, leaf: attitude, length of inflorescence, plant habitus.

Also, there was negative correlation between fruit weight, fruit length and Ty3-a gene. Consequently, we identified some morphological markers such as stem at first inflorescence, stem length of internode, leaf attitude, plant habitus, length of inflorescence, status of calix position of petal, fruit weight and fruit length linked to $T y$ - $3 a$ which can be used in selection for TLYCV resistant breeding programme.

\section{Conflict of Interests}

The authors declare that there are no conflicts of interest related to this article.

\section{References}

Balliu A, Hallidri M (2002). Combining ability test between some tomato genotypes. Acta Horticulturae 579:123-126.

Chen FQ, Foolad MR, Hyman J, Clair DA, Beeleman RB (1999). Mapping QTLs for lycopene and other fruit traits in a Lycopersicon esculentum $\mathrm{x}$ L. pimpinellifolium cross and comparison of QTLs across tomato species. Molecular Breeding 5:283-299.

Cho JJ, Custer DM, Brommonschenkel SH, Tanksley SD (1995). Conventional breeding: host-plant resistance and the use of molecular markers to develop resistance to tomato spot wilt virus in vegetables. Tospoviruses and Thrips of Floral and Vegetable Crops 431:367-378.

Consuegra OG, Gómez MP, Zubiaur YM (2015). Pyramiding TYLCV and TSWV resistance genes in tomato genotypes. Revista de Protección Vegetal 30(2):161-164.

Czosnek H, Laterrot H (1997). A worldwide survey of tomato yellow leaf curl viruses. Archives of Virology 142:1391-1406.

De Castro AP, Blanca JM, Díez MJ, Viñals FN (2007). Identification of a CAPS marker tightly linked to the tomato yellow leaf curl disease resistance gene $T y-1$ in tomato. European Journal of Plant Pathology 117:347-356.

Doganlar S, Frary A, Daunay MC, Lester RN, Tanksley SD (2002). A comparative genetic linkage map of eggplant (Solanum melongena) and its implications for genome evolution in the Solanaceae. Genetics 161(4):1697-1711.

Doyle JJ, Doyle J (1987). A rapid DNA isolation procedure from small quantities of fresh leaf tissues. Phytochemical Bulletin 19:11-15.

FAO (2017). Statistics of food and agriculture organization of the united nations.

Foolad MR (2007). Genome mapping and molecular breeding of tomato. International journal of plant genomics.

Ghanim M, Czosnek H (2000). Tomato yellow leaf curl gemini virus (TYLCV-Is) is transmitted among whiteflies (Bemisia tabaci) in a sex-related manner. Journal of Virology 74:4738-4745.

Gómez O, Piñón M, Martínez Y, Quiñones M, Fonseca D, Laterrot H (2004). Breeding for resistance to begomovirus in tropicadapted tomato genotypes. Plant Breeding 123:275-279. 
Grandillo S, Ku HM, Tanksley SD (1999). Identifying the loci responsible for natural variation in fruit size and shape in tomato. Theoretical and Applied Genetics 99(6):978-987.

Hanson P, Lu SF, Wang JF, Chen W, Kenyon L, Tan CW, ... Ledesma D (2016). Conventional and molecular marker-assisted selection and pyramiding of genes for multiple disease resistance in tomato. Scientia Horticulturae 201:346-354.

Hassan AA, Wafi MS, Quronfilah NE, Obaji UA, Al-Rayis MA, Al-Izabi F (1991). Screening for tomato yellow leaf curl virus resistance in wild and domestic Lycopersicon accessions. Tomato Genetics Cooperative 41:19-21.

Jensen KS, Van Betteray B, Smeets J, Yuanfu J, Scott JW, Mejia L, ... Maxwell DP (2007). Co dominant SCAR Marker, P6-25, for Detection of the ty-3, Ty-3, and Ty-3a alleles at $25 \mathrm{cM}$ of chromosome 6 of tomato. http://144.92.198.11/GeminivirusResistantTomatoes/Markers/MAS-Protocols/Ty3a-allele.pdf

Ji Y, Schuster DJ, Scott JW (2007). Ty-3, a begomovirus resistance locus near the Tomato yellow leaf curl virus resistance locus Ty-1 on chromosome 6 of tomato. Molecular Breeding 20(3):271-284.

Mejía L, Teni RE, Vidavski F, Czosnek H, Lapidot M, Nakhla MK, Maxwell DP (2005). Evaluation of tomato germplasm and selection of breeding lines for resistance to begomoviruses in Guatemala. Acta Horticulturae 695:251-255.

Mutlu N, Demirelli A, Ilbi H, Ikten C (2015). Development of co-dominant SCAR markers linked to resistant gene against the Fusarium oxysporum f. sp. radicis-lycopersici. Theoretical and Applied Genetics 128(9):1791-1798.

Oerke EC (2006). Crop losses to pests. The Journal of Agricultural Science 144(1):31-43.

Padidam M, Beachy RN, Fauquet CM (1995). Tomato leaf curl geminivirus from India has a bipartite genome and coat protein is not essential for infectivity. Journal of General Virology 76(1):25-35.

Picó B, Díez MJ, Nuez F (1996). Viral diseases causing the greatest economic losses to the tomato crop. II. The tomato yellow leaf curl virus-a review. Scientia Horticulturae 67(3-4):151-196.

Polston JE, Anderson PK (1997). The emergence of whitefly-transmitted geminiviruses in tomato in the western hemisphere. Plant Disease 81(12):1358-1369.

Rani IC, Veeraragavathatham D, Sanjutha S (2008). Studies on correlation and path coefficient analysis on yield attributes in root knot nematode resistant F1 hybrids of tomato. Journal of Applied Sciences Research 4(3):287-295.

Scott JW, Schuster DJ (1991). Screening of accessions for resistance to the Florida tomato geminivirus. Tomato Genetics Cooperative 41:48-50.

Scott JM (2007). Breeding for resistance to viral pathogens. Genetic Improvement of Solanaceous Crops 2:457-485.

Tanksley SD (2004). The genetic developmental and molecular bases of fruit size and shape variation in tomato. The Plant Cell 16:181-189.

Verlaan MG, Hutton SF, Ibrahem RM, Kormelink R, Visser RG, Scott JW, ... Bai Y (2013). The tomato yellow leaf curl virus resistance genes $\mathrm{Ty}-1$ and $\mathrm{Ty}-3$ are allelic and code for DFDGD-class RNA-dependent RNA polymerases. PLoS Genetics 9(3):e100339.

Zamir D, Ekstein-Michelson I, Zakay Y (1994). Mapping and introgression of a tomato yellow leaf curl virus tolerance gene, Ty1. Theoretical and Applied Genetics 88 (2):141-146.

Zeidan M, Czosnek H (1991). Acquisition of tomato yellow leaf curl virus by the whitefly Bemisia tabaci. Journal of General Virology 72(11):2607-2614.
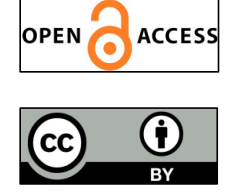

The journal offers free, immediate, and unrestricted access to peer-reviewed research and scholarly work. Users are allowed to read, download, copy, distribute, print, search, or link to the full texts of the articles, or use them for any other lawful purpose, without asking prior permission from the publisher or the author.

License - Papers published in Notulae Botanicae Horti Agrobotanici Cluj-Napoca are Open-Access, distributed under the terms and conditions of the Creative Commons Attribution (CC BY) License.

(c) Articles by the authors; UASVM, Cluj-Napoca, Romania. The journal allows the author(s) to hold the copyright/to retain publishing rights without restriction. 